\title{
PEMANFAATAN LIMBAH PRODUK PERTANIAN DALAM PAKAN BUATAN YANG BERPROBIOTIK TERHADAP EFISIENSI PAKAN, PERTUMBUHAN, DAN KELULUSHIDUPAN LELE DUMBO (Clarias gariepinus)
}

\author{
Suminto, Titik Susilowati, Sarjito, Diana Chilmawati \\ Departemen Akuakultur Fakultas Perikanan dan Ilmu Kelautan, Universitas Diponegoro \\ Jl. Prof. Soedarto, SH, Tembalang, Semarang, Jawa Tengah - 50275, \\ Telp/Fax. +62247474698
}

\begin{abstract}
ABSTRAK
Tingginya harga pakan dan rendahnya efisiensi pemanfaatan pakan merupakan masalah dalam pengembangan budidaya ikan lele dumbo. Tujuan penelitian ini adalah untuk mengetahui penggunaan limbah produk pertanian terhadap efisiensi pakan, pertumbuhan, dan kelulushidupan lele dumbo (Clarias gariepinus). Penelitian ini menggunakan metode eksperimen dengan 2 perlakuan dengan penambahan probiotik (A) dan tanpa penambahan probiotik (B) dan masing-masing 3 kali ulangan telah dirancang melalui rancangan acak lengkap (RAL). Pakan uji yang digunakan adalah tepung ari jagung, ari gandum, bungkil kedelai, bekatul dan telur ayam afkir yang telah dibuat sebagai pakan pellet mengandung protein sebanyak 32,58\%. Ikan uji yang digunakan adalah benih ikan lele dumbo (C. gariepinus) dengan bobot rerata 2,04 $\pm 0,05 \mathrm{~g}$ dan kepadatan awal sebanyak $350 \mathrm{ekor} / \mathrm{m}^{2}$ luas kolam dengan periode pemeliharaan selama 60 hari. Hasil penelitian ini bahwa pakan buatan mandiri dengan bahan dari limbah pertanian memberikan hasil nilai efisiensi pemanfaatan pakan (EPP): $84,10 \pm 1,83 \%$, rasio konversi pakan (FCR): 1,03 $\pm 0,02$, dan tingkat kelulushidupan (SR): 95,79 \pm Penambahan probiotik pada pakan buatan mandiri dengan bahan baku dari limbah pertanian memberikan pengaruh yang nyata $(\mathrm{p}<0,05)$ menghasilkan efisiensi pemanfaatan pakan (EPP): 99,56 $\pm 5,64 \%$, rasio konversi pakan (FCR):

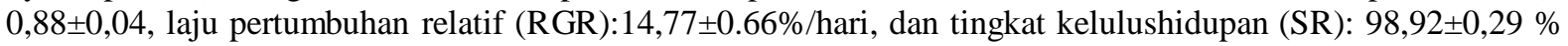
yang nilainya lebih tinggi dari pemberian pakan yang tanpa pemberian probiotik.
\end{abstract}

Kata kunci: Tepung Telur Ayam Afkir, Ikan Lele Dumbo, Pertumbuhan, Kelulushidupan

\begin{abstract}
The high price of feed and the low efficiency of feed utilization is a problem in the development of African catfish cultivation. The purpose of this study was to determine the use of agricultural product waste on feed efficiency, growth, and survival of African catfish (Clarias gariepinus). This study used an experimental method with 2 treatments with the addition of probiotics $(A)$ and without the addition of probiotics $(B)$ and each of the 3 replications was designed through a completely randomized design (CRD). The test feed used was corn flour, wheat flour, soybean meal, rice bran and chicken eggs which had been made as pellet feed containing 32.58\% protein. The test fish used was African catfish (C. gariepinus) with an average weight of $2.04 \pm 0.05 \mathrm{~g}$ and an initial density of 350 tails / $m 2$ of pond area with a maintenance period of 60 days. The results of this study that self-made feed with materials from agricultural waste results in the value of feed utilization efficiency (EPP): $84.10 \pm 1.83 \%$, feed conversion ratio $(F C R): 1.03 \pm 0.02$, and survival rate $(S R): 95.79 \pm$ The addition of probiotics to self-made feed with raw materials from agricultural waste gave a significant effect $(p<0.05)$ resulting in feed utilization efficiency $(E P P): 99.56 \pm 5.64 \%$, feed conversion ratio $(F C R): 0.88 \pm 0.04$, the relative growth rate $(R G R): 14.77 \pm 0.66 \%$ / day, and the survival rate $(S R): 98.92 \pm 0.29 \%$ whose value is higher than feeding which is without probiotics
\end{abstract}

Keywords: Chicken Egss Rejects Flour, Dumbo Ctafish, Growth, Survival Rate

*Corresponding author: suminto57@gmail.com 


\section{PENDAHULUAN}

Kebutuhan lele dumbo (Clarias gariepinus) dari tahun ke tahun semakin meningkat, seiring dengan bertambahnya jumlah penduduk yang semakin meningkat, tetapi pencapaian produksi perikanan masih dibawah target hanya $82,36 \%$. Lele dumbo strain sangkuriang sangat digemari masyarakat karena selain rasanya yang enak juga harga terjangkau. Namun masih ada beberapa kendala dalam usaha budidaya lele dumbo, salah satunya adalah masalah pakan. Mahalnya harga pakan ikan dan sebagian besar komponen pakan masih impor sehingga keuntungan pembudidaya relatif kecil yang mengakibatkan menurunnya minat pembudidaya untuk memelihara lele dumbo (Trisnawati et al., 2014).

Biaya pakan lele menyerap biaya 60 $70 \%$ dari total biaya produksi yang dikeluarkan (Arief et al., 2014). Kualitas suatu pakan ditentukan oleh komposisi bahan yang digunakan. Semakin banyak kandungan protein maka kualitas pakan tersebut semakin baik. Hal ini sesuai dengan pendapat Trisnawati et al. (2014) bahwa pakan yang dikonsumsi dapat menunjang pertumbuhan dan kelulushidupan sehingga pakan yang diberikan harus sesuai dengan kebutuhan ikan baik jumlah maupun kualitasnya.
Alternatif pemecahan yang dapat diupayakan adalah dengan membuat pakan buatan sendiri melalui teknik sederhana dengan memanfaatkan sumber-sumber bahan baku yang relatif murah (Anggraeni dan Rahmiati, 2016). Limbah produk pertanian merupakan sumber bahan baku yang nilai nutrisinya masih cukup baik untuk digunakan sebagai pakan ikan, terutama sumber karbohidrat selain kandungan protein dan lemaknya. Produksi penangkapan ikan di laut oleh nelayan juga menghasilkan hasil sampingan berupa ikan rucah, baik berbentuk basah maupun berbentuk kering yang merupakan sumber bahan pakan dari protein hewani yang lebih murah (Rp.4.500 s/d Rp.5.000-/kg) dari pada tepung ikan impor (Rp.15.000-/kg). Selain itu sumber protein hewani bahan baku pakan ikan bisa disubstitusi dari tepung telur afkir yang diproduksi oleh pabrik pembibitan ayam yang nilai harganya juga sangat murah (Rp.600-/kg), dengan memanfaatkan limbah produk pertanian seperti tersebut diatas dan teknologi pencampuran serta pengaturan komposisi kebutuhan nutrisi ikan lele, baik protein, karbohidrat, lemak maupun mineral dan vitamin yang dibutuhkan lele, maka harga bahan baku untuk membuat pakan lele akan lebih murah.

Pemanfaatan limbah pertanian sebagai bahan baku pakan lele dumbo dapat 
dilakukan dengan penambahan probiotik sebelumnya agar kandungan nutrisi yang terkandung di dalamnya dapat tercerna oleh lele dumbo. Probiotik pada pakan mampu memperbaiki kualitas pencernaan lele dumbo sehingga pakan lebih banyak terserap pada tubuh ikan. Bakteri di dalam saluran pencernaan ikan dapat mensekresikan enzim-enzim pencernaan seperti protease dan amilase (Irianto, 2003). Enzim yang disekresikan ini jumlahnya meningkat juga sesuai dengan jumlah dosis probiotik yang diberikan yang pada gilirannya jumlah pakan yang dicerna juga meningkat. Kennedy et al. (1998) menyatakan penggunaan Bacillus sp. mampu memperbaiki kualitas dan sintasan Centropomus undecimalis. Bacillus sp. mampu meningkatkan absorpsi pakan melalui peningkatan konsentrasi protease pada saluran pencernaan, memperbaiki pertumbuhan dan mengurangi jumlah bakteri yang berpotensi patogen di dalam intestinumnya.

Beberapa penelitian telah dilakukan untuk mencoba mencari pengganti bahan pakan ikan dengan harga murah. Salah satunya adalah penelitian yang telah dilakukan oleh Yoel et al., (2016) yaitu pemberian tepung usus ayam sebagai pengganti tepung ikan pada pakan ikan lele dumbo (C. gariepinus) memberikan pengaruh nyata pada pertumbuhan mutlak ikan lele dumbo (C. gariepinus). Pemanfaatan limbah pertanian dapat digunakan untuk bahan baku pakan lele dumbo untuk menekan biaya produksi budidaya lele dumbo. Oleh karena itu perlu penelitian tentang pemanfaatan limbah pertanian pada pakan buatan berprobiotik terhadap efisiensi pemanfaatan pakan, pertumbuhan, dan kelulushidupan ikan lele dumbo ( $C$. gariepinus).

\section{METODE PENELITIAN}

Persiapan bahan baku pakan yaitu tepung ikan, tepung bungkil kedelai, tepung terigu, tepung dedak, tepung jagung, minyak ikan, minyak jagung, vitmin mix, dan CMC (Tabel 1). Selain itu digunakan penambahan tepung limbah telur afkir sebagai tambahan sumber protein hewani. Bahan tersebut disaring hingga memiliki ukuran yang homogen. Proses penentuan formulasi pakan dalam pembuatan pakan uji didasarkan dengan kebutuhan protein ikan lele dumbo yaitu $32 \%$.

Proses pembuatan pakan uji dengan mencampur semua bahan pakan secara merata mulai dari bahan persentasenya 
paling kecil hingga besar, kemudian ditambah air hangat sedikit demi sedikit hingga kalis dan tidak lengket ditangan. Pakan digiling dengan pencetak pelet, kemudian dimasukkan ke dalam oven dengan suhu kurang dari $40^{\circ} \mathrm{C}$ sampai kering, agar tidak mengurangi nilai nutrisi kandungan protein dalam pakan.

Pakan uji kemudian diberi tambahan probiotik. Bakteri probiotik yang digunakan mengandung jenis bakteri Lactobacillus casei, Saccharomyces cerevisiae, Bacillus subtilis, Bacillus lycheniformis, dan Lactobacillus plantarum (hasil kultur Laboratorium Akuakultur, Fakultas Perikanan dan Ilmu Kelautan). Kepadatan probiotik yang digunakan yaitu $10^{7} \mathrm{CFU} / g r a m$ pakan. Pembuatan pakan berprobiotik diawali dengan mengambil probiotik pakan sebanyak 2,5 ml, kemudian $5 \mathrm{ml}$ molase, $250 \mathrm{ml}$ air biasa (tap water) atau air kolam, kemudian dicampur secara homogen dengan cara disemprotkan kepermukaan pakan pellet. Setelah pakan tercampur secara homogen, selanjutnya diinkubasi pada suhu ruangan selama 48 jam di wadah ember tertutup agar terjadi proses fermentasi, dan setelahnya pakan siap diberikan untuk pakan lele.
Tabel 1. Komposisi dan Analisa Proksimat Pakan yang Digunakan Selama Penelitian (\% Bobot Kering)

\begin{tabular}{|c|c|c|}
\hline No. & $\begin{array}{l}\text { Bahan Penyusun } \\
\text { pakan }\end{array}$ & Persentase \\
\hline 1 & Tp. Telur Ayam Afkir & 22,50 \\
\hline 2 & Tp. Ikan & 22,50 \\
\hline 3 & Tp. Ari Jagung & 20,00 \\
\hline 4 & Tp. Ari Terigu & 4,00 \\
\hline 5 & Tp. Dedak & 3,00 \\
\hline 6 & Tp. Wheat Brand & 15,00 \\
\hline 7 & Tp. Bungkil Kedelai & 13,00 \\
\hline 8 & Minyak Ikan & 2,00 \\
\hline 9 & Vit-Min Mix & 1,00 \\
\hline & Total & 100,00 \\
\hline & Protein $(\%)$ & 32,58 \\
\hline & Lemak $(\%)$ & 10,69 \\
\hline & Energi $(\mathrm{kkal} / \mathrm{g})^{*}$ & 285,78 \\
\hline & ssio E/P (kkal/g P)** & 8,77 \\
\hline \multicolumn{3}{|c|}{$\begin{array}{l}\text { * Berdasarkan perhitungan DE (digestable } \\
\text { energy) dengan asumsi untuk protein } \\
=3,5 \mathrm{kkal} / \mathrm{g} \text {, lemak }=8,1 \mathrm{kkal} / \mathrm{g} \text {, BETN } \\
=2,5 \mathrm{kkal} / \mathrm{g} \text { (Wilson, 1982). }\end{array}$} \\
\hline \multicolumn{3}{|c|}{$\begin{array}{l}\text { ** Menurut De Silva (1987), nilai E/P bagi } \\
\text { pertumbuhan optimal ikan berkisar } \\
\text { antara } 8-12 \mathrm{kkal} / \mathrm{g} \text {. }\end{array}$} \\
\hline
\end{tabular}

Ikan uji yang digunakan dalam penelitian ini adalah benih ikan lele dumbo (C. gariepinus) berukuran 5-6 $\mathrm{cm}$ dengan rata-rata bobot awal $2.04 \pm 0.05 \mathrm{~g}$ berasal dari Balai Pembenihan Ikan Air Tawar Ngrajek, Jawa Tengah. Jumlah benih yang ditebar untuk tiap perlakuan dan ulangan sebanyak 1 ekor/ liter, Sebelum dilakukan penelitian, benih lele uji di aklimatisasi terlebih dahulu selama 5 hari di dalam kolam terpal dengan kepadatan sebanyak 1 ekor/ liter. Setelah aklimatisasi dan benih 
lele tersebut ditebar kedalam 6 (enam) kolam terpal yang sudah disiapkan terlebih dahulu yang masing-masing berukuran 3 x 5 x $1 \mathrm{~m}\left(15 \mathrm{~m}^{2}\right)$ dengan kedalaman air $80 \mathrm{~cm}$. Padat tebar benih lele yang diberikan kedalam setiap kolam pemeliharaan sebanyak $350 \mathrm{ekor} / \mathrm{m}^{2}$.

Pemberian pakan selama 60 hari pemeliharaan pada penelitian ini diberikan secara Fix feeding rate dengan catatan 20 hari pertama menggunakan $6 \%$ bobot biomassa, kemudian 20 hari berikutnya diberikan sebanyak 5\% bobot biomassa, dan hari selanjutnya untuk 10 hari ke-5 diberikan $4 \%$ bobot biomassa dan $3 \%$ diberikan pada 10 hari ke-6.

Metode penelitian yang digunakan adalah metode eksperimen. Menurut Srigandono (1992), metode eksperimen merupakan suatu usaha terencana untuk mengungkap fakta-fakta baru atau menguatkan teori bahkan membantah penelitian-penelitian yang sudah ada. Rancangan percobaan yang digunakan dalam penelitian ini adalah rancangan acak lengkap (RAL). Menurut Sudjana (1991), bahwa RAL digunakan pada penelitian yang bersifat homogen (perlakuan tunggal) dan perlakuan dikenakan sepenuhnya secara acak terhadap unit-unit eksperimen. Penelitian ini menggunakan 2 perlakuan dan setiap perlakuan diulang sebanyak 3 kali, Perlakuan yang dimaksud adalah : Perlakuan A yaitu pakan dengan penambahan probiotik, dan Perlakuan B yaitu pakan tanpa penambahkan probiotik

Pengumpulan data yang meliputi variabel pertumbuhan yaitu total konsumsi pakan (TKP), efisiensi pemanfaatan pakan (EPP), rasio konversi pakan (FCR), protein efisiensi rasio (PER), laju pertumbuhan relatif (RGR) dan kelulushidupan (SR). Variabel kualitas air yaitu DO, pH, suhu, dan kandungan ammonia yang tidak terionisasi di dalam air $\left(\mathrm{NH}_{3}\right.$ dalam bentuk gas).

Perhitungan nilai tingkat konsumsi pakan dihitung dengan menggunakan rumus Pereira et al.,(2007) sebagai berikut:

$$
\mathrm{TKP}=\mathrm{F} 1-\mathrm{F} 2
$$

Dimana TKP yaitu Total konsumsi pakan (g), F1 yaitu jumlah pakan awal (g), F2 yaitu jumlah pakan akhir (g)

Perhitungan nilai efisiensi pemanfaatan pakan (EPP) dihitung dengan menggunakan rumus Tacon (1987), sebagai berikut:

$$
\begin{array}{cl}
\text { EPP } & \begin{array}{l}
\mathrm{W}_{\mathrm{t}}- \\
\mathrm{W}_{\mathrm{o}} \mathrm{x}
\end{array} \\
= & \frac{\mathrm{F}}{\mathrm{F}} 100 \%
\end{array}
$$


Dimana EPP yaitu Efisiensi pemanfaatan pakan (\%), Wt yaitu bobot total ikan pada akhir pemeliharaan (g), Wo yaitu bobot total ikan pada awal pemeliharaan $(\mathrm{g})$, F yaitu jumlah pakan yang dikonsumsi selama penelitian (g)

Perhitungan nilai rasio konversi pakan (FCR) dihitung dengan menggunakan rumus Effendi (1997), sebagai berikut:

$$
\mathrm{FCR}=\frac{\mathrm{F}}{\frac{(\mathrm{Wt}+\mathrm{d})-}{\mathrm{W} 0}}
$$

Dimana FCR yaitu rasio konversi pakan, F yaitu jumlah pakan yang diberikan selama penelitian $(\mathrm{g})$, Wt yaitu bobot total ikan pada akhir penelitian (g), W0 yaitu bobot total ikan pada awal penelitian (g), D yaitu bobot ikan yang mati selama penelitian $(\mathrm{g})$.

Perhitungan nilai protein efisiensi rasio (PER) dengan menggunakan rumus Tacon (1987), sebagai berikut:

Dimana PER yaitu Protein efisiensi rasio (\%) Wt yaitu bobot total ikan pada akhir pemeliharaan (g), Wo yaitu bobot total ikan pada awal pemeliharaan (g), Pi

$$
\mathrm{PER}=\frac{\mathrm{W}_{\mathrm{t}}-\mathrm{W}_{\mathrm{o}}}{\mathrm{Pi}} \times 100 \%
$$

yaitu berat pakan yang dikonsumsi x \% protein pakan.

Menurut Takeuchi (1988), laju pertumbuhan relatif atau relative growth rate (RGR) ikan dihitung menggunakan rumus sebagai berikut: $\mathrm{RGR}=(\mathrm{Wt}-$ $\left.\mathrm{W}_{0} / \mathrm{W}_{0} \mathrm{xt}\right) \times 100 \% /$ hari, dimana RGR yaitu Laju pertumbuhan relatif (\% per hari), $\mathrm{W}_{\mathrm{t}}$ yaitu bobot total ikan pada akhir pemeliharaan $(\mathrm{g}), \mathrm{W}_{\mathrm{o}}$ yaitu bobot total ikan pada awal pemeliharaan (g), t yaitu waktu pemeliharaan (hari).

Kelulushidupan atau survival rate (SR) dihitung untuk mengetahui tingkat kematian kematian ikan uji selama penelitian, kelulushidupan dapat dihitung berdasarkan rumus Effendi (1997):

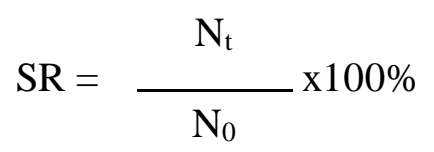

Dimana SR yaitu Tingkat kelulushidupan ikan (\%), $\mathrm{N}_{\mathrm{t}}$ yaitu jumlah ikan pada akhir penelitian (ekor), $\mathrm{N}_{0}$ yaitu jumlah ikan pada awal penelitian (ekor)

Parameter data kualitas air yang diukur meliputi DO, pH, suhu, amonia. DO diukur dengan menggunakan DO meter, $\mathrm{pH}$ diukur dengan $\mathrm{pH}$ meter, suhu diukur dengan termometer dan untuk pengukuran amonia, sampel air diukur di laboratorium teknik lingkungan, UNDIP.

Analisis data meliputi tingkat konsumsi pakan (TKP), efisiensi pemanfaatan pakan (EPP), rasio konversi pakan (FCR), Protein Efficiency Ratio (PER), laju pertumbuhan spesifik (SGR) kelulushidupan (SR) dan kualitas air. 
Variabel yang didapatkan kemudian dianalisis menggunakan uji $\mathrm{t}$ (t-test). selang kepercayaan 95\%, sebelum dilakukan uji t (t-test), data terlebih dahulu dilakukan uji normalitas, uji homogenitas, dan uji addivitas guna mengetahui bahwa data bersifat normal, homogen dan aditif untuk dilakukan uji lebih lanjut yaitu uji $\mathrm{t}$ (t-test). Data kualitas air dianalisis secara deskriptif.

\section{HASIL DAN PEMBAHASAN}

\section{Hasil}

Hasil penelitian pemanfaatan tepung telur ayam afkir pakan buatan terhadap pemanfaatan pakan meliputi nilai TKP; EPP; FCR; PER; RGR; dan SR tersaji pada Tabel 2.

Tabel 2. Nilai Rata-rata TKP, EPP, FCR, PER, RGR, dan SR selama Pemeliharaan

\begin{tabular}{|c|c|c|}
\hline $\begin{array}{l}\text { Perlaku } \\
\text { yariabel } \\
\text { yang diukur }\end{array}$ & A & B \\
\hline TKP (g/ekor) & $68,00 \pm 0,03^{a}$ & $68,00 \pm 0,03^{a}$ \\
\hline $\operatorname{EPP}(\%)$ & $99,56 \pm 5,64^{\mathrm{a}}$ & $84,10 \pm 1,83^{b}$ \\
\hline FCR & $0,88 \pm 0,04^{\mathrm{a}}$ & $1,03 \pm 0,02^{\mathrm{b}}$ \\
\hline PER (\%) & $3,17 \pm 0,18^{\mathrm{a}}$ & $2,63 \pm 0,06^{\mathrm{b}}$ \\
\hline RGR (\%/hari) & $14,77 \pm 0,66^{\mathrm{a}}$ & $11,73 \pm 0,74^{b}$ \\
\hline SR $(\%)$ & $98,79 \pm 0,29^{a}$ & $95,79 \pm 0,16^{\mathrm{b}}$ \\
\hline
\end{tabular}

Keterangan:

Nilai rerata dengan huruf superscript yang berbeda menunjukkan adanya perbedaan yang nyata $(\mathrm{P}<0,05)$ dan huruf superscript yang sama menunjukkan tidak berbeda nyata.

Sesuai hasil yang terdapat pada tabel diketahui nilai total konsumsi pakan (TKP) antar perlakuan tidak terdapat perbedaan yang nyata, rata-rata TKP perlakuan pakan dengan penambahan probiotik (A) adalah $68,00 \pm 0,03$ g/ekor dan perlakuantanpa penambahan probiotik (B) adalah $68,00 \pm 0,03$ g/ekor. Nilai efisiensi pemanfaatan pakan (EPP) antar perlakuan perlakuan berbeda nyata, rata-rata EPP perlakuan pakan dengan penambahan probiotik (A) adalah sebesar 99,56 $\pm 5,64 \%$, perlakuan tanpa penambahan probiotik (B) adalah sebesar $84,10 \pm 1,83 \%$. Nilai rasio konversi pakan (FCR) antar perlakuan terdapat perbedaan yang nyata, rata-rata FCR perlakauan pakan dengan penambahan probiotik (A) $0.88 \pm 0.04$, perlakuan tanpa penambahan probiotik $\mathrm{B}$ sebesar 1,03 $\pm 0,02$, Nilai rata-rata rasio efisiensi protein (PER) antar perlakuan terdapat pebedaan yang nyata, rata-rata PER perlakuan pakan dengan penambahan probiotik (A) adalah $3,17 \pm 0.18 \%$ dan perlakuantanpa penambahan probiotik (B) adalah $2,63 \pm 0.06 \%$. Nilai rata-rata laju pertumbuhan relatif (RGR) pada perlakuan pakan dengan penambahan probiotik (A) adalah $14,77 \pm 0.66 \% /$ hari dan 
perlakuantanpa penambahan probiotik (B) adalah $11,73 \pm 0.74 \%$ /hari. Nilai rata-rata kelulushidupan (SR) antar perlakuan berbeda nyata, rata-rata SR perlakuan pakan dengan penambahan probiotik (A) adalah $98,92 \pm 0,29 \%$ dan perlakuan tanpa penambahan probiotik (B) adalah $95,79 \pm 0,16 \%$.

Berdasarkan data efisiensi pemanfaatan pakan, laju pertumbuhan relatif dan kelulushidupan pada ikan lele dumbo (C. gariepinus $)$ selama pemeiharaan dapat dibuat histogram pada Gambar 1, 2, dan 3.

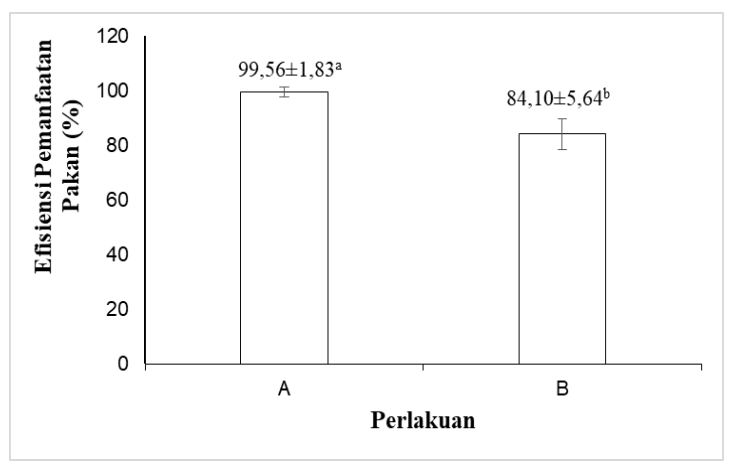

Gambar 1. Nilai Efisiensi Pemanfaatan Pakan Ikan Lele Dumbo(C. gariepinus) Selama Pemeliharaan

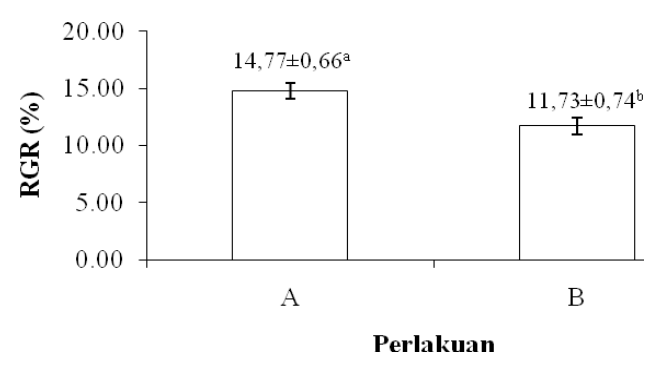

Gambar 2. Nilai Laju Pertumbuhan Relatif Ikan Lele Dumbo (C. gariepinus) Selama Pemeliharaan

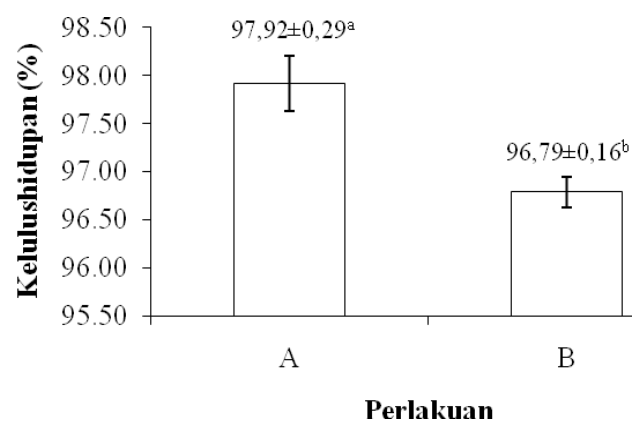

Gambar 3. Nilai Kelulushidupan Ikan Lele Dumbo (C. gariepinus) Selama Pemeliharaan

Hasil pengukuran parameter kualitas air pada media ikan lele dumbo $(C$. gariepinus) selama pemeliharaan tersaji pada Tabel 3.

Tabel 3. Hasil Pengukuran Parameter Kualitas Air selama Pemeliharaan

\begin{tabular}{ccc}
\hline & Kisaran \\
Parameter & Nilai & \\
Kualitas & Parameter & Pustaka \\
Air & Kualitas & (Kelayakan) \\
& Air & \\
\hline Suhu $\left({ }^{0} \mathrm{C}\right)$ & $25-30$ & $22-32^{\mathrm{a}}$ \\
DO $(\mathrm{mg} / \mathrm{l})$ & $4-6$ & $>3 \mathrm{mg} / \mathrm{l}^{\mathrm{a}}$ \\
$\mathrm{pH}$ & $7-7,5$ & $6,5-8,6^{\mathrm{b}}$ \\
$\mathrm{NH}_{3}(\mathrm{mg} / \mathrm{l})$ & $0-0,035$ & $<1^{\mathrm{a}}$ \\
\hline Keterangan: ${ }^{\mathrm{a}} \mathrm{SNI}(2015),{ }^{\mathrm{b}}$ Ahmadi et al., $^{(2012)}$
\end{tabular}

Kualitas air pada media pemeliharaan ikan lele dumbo (C. gariepinus) pada penelitian ini layak untuk kebutuhan hidup ikan lele dumbo. Hasil pengamatan kualitas air menunjukkan kondisi yang optimal bagi kehidupan ikan lele dumbo (C. gariepinus). 


\section{Pembahasan}

Nilai Total Konsumsi Pakan dengan penambahan probiotik A sama dengan perlakuan tanpa penambahan probiotik B

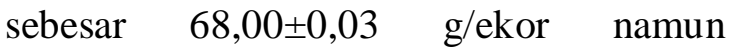
memberikan nilai EPP, FCR, PER, RGR dan SR yang berbeda antara kedua perlakuan. Menurut Abidin et al., (2015), besar kecilnya total konsumsi pakan pada ikan dipengaruhi oleh beberapa faktor, antara lain sifat fisik pakan misalnya bau, rasa, ukuran, dan warna. Faktor lain yang berpengaruh adalah kualitas air seperti suhu perairan. Perairan yang memiliki suhu tinggi akan mempengaruhi proses metabolisme ikan, semakin tinggi suhu akan menyebabkan ikan cenderung mengkonsumi pakan lebih banyak atau proses metabolisme dari ikan akan meningkat. Tingkat konsumsi pakan yang lebih tinggi akan cenderung menghasilkan pertumbuhan yang lebih tinggi dibandingkan jika tingkat konsumsi pakannya lebih sedikit. Sesuai pendapat Amin (2007) bahwa tingkat konsumsi pakan yang lebih tinggi akan cenderung menghasilkan pertumbuhan yang lebih tinggi dibandingkan jika tingkat konsumsi pakannya lebih sedikit.

Berdasarkan nilai EPP pada perlakuan pakan dengan penambahan probiotik (A) adalah sebesar $99,56 \pm 5,64 \%$ dan perlakuan tanpa penambahan probiotik (B) sebesar $84,10 \pm 1,83 \%$, keduanya dalam termasuk baik karena memiliki nilai EPP di atas 50\%. Trisnawati et al., (2014) menyatakan bahwa semakin tinggi kandungan protein yang terdapat dalam pakan akan meningkatkan daya cerna ikan terhadap pakan. Hal ini diperkuat dengan pendapat Amalia et al., (2013), peningkatan nilai efisiensi pemanfaatan pakan menunjukkan bahwa pakan yang dikonsumsi memiliki kualitas yang baik, sehingga dapat dimanfaatkan secara efisien. Hasil penelitian ini menunjukkan bahwa penambahan probiotik pada pakan lele dumbo berpengaruh nyata terhadap efisiensi pemanfaatan pakan. Efisiensi pemanfaatan pakan pada pakan yang ditambahkan probiotik menunjukkan nilai yang lebih baik dibandingkan dengan pakan tanpa ditambahkan probiotik. Menurut Watson et al. (2008) menyatakan bahwa probiotik merupakan makanan tambahan dalam bentuk mikroba hidup, dimana dapat memberi pengaruh menguntungkan bagi inang dengan meningkatkan keseimbangan mikroba dalam saluran pencernaan.

Aplikasi teknologi bioflok berperan penting dalam meningkatkan efisiensi pemanfaatan pakan oleh kultivan budidaya. Menurut Widanarni et al. (2009) 
bahwa efisiensi pakan pada perlakuan dengan aplikasi teknologi bioflok lebih tinggi karena adanya peningkatan biomassa bioflok sebagai sumber nutrisi atau makanan tambahan untuk kultivan budidaya. Hal ini didukung oleh hasil penelitian Ahmadi et al. (2012) pemberian probiotik dengan dosis $10^{8} \mathrm{sel} / \mathrm{mL}$ hanya memberikan nilai efisiensi pemanfaatan pakan sebesar 43,93\%. Efisiensi pemanfaatan pakan pada pakan yang ditambahkan probiotik menunjukkan nilai yang lebih baik dibandingkan dengan pakan tanpa ditambahkan probiotik. Hal ini diduga pakan dengan campuran probiotik memiliki kualitas yang lebih baik dibandingkan dengan pakan tanpa probiotik, Semakin tinggi nilai EPP berarti kualitas pakan tersebut semakin baik (Afrianto dan Liviawaty, 2005).

Nilai rasio konversi pakan (FCR) antar perlakuan terdapat perbedaan yang nyata, rata-rata FCR perlakauan pakan dengan penambahan probiotik (A) $0.88 \pm 0.04$, perlakuan tanpa penambahan probiotik B sebesar 1,03 $\pm 0,02$. Semakin kecil rasio konversi pakan maka pakan yang dikonsumsi itu bagus untuk menunjang pertumbuhan ikan peliharaan dan sebaliknya semakin besar rasio konversi pakan menunjukkan pakan yang diberikan tidak efektif untuk menunjang pertumbuhan ikan (Fujaya, 2004). Besar kecilnya nilai konversi pakan merupakan gambaran tingkat efisiensi pakan yang diberikan. Menurut Ardita et al., (2015) semakin rendah nilai FCR menunjukkan bahwa semakin efisien pakan dan pakan yang dimakan digunakan dengan baik oleh ikan untuk pertumbuhan. Menurut Fran dan Junius, (2013) nilai konversi pakan sebenarnya bukan merupakan angka mutlak, karena tidak hanya ditentukan oleh kualitas pakan, akan tetapi dipengaruhi pula oleh faktor-faktor lain seperti jenis ikan dan ukuran ikan, jumlah padat tebar, kualitas air, dan faktor genetik.

Nilai rata-rata rasio efisiensi protein (PER) antar perlakuan terdapat pebedaan yang nyata, rata-rata PER perlakuan pakan dengan penambahan probiotik (A) adalah $3,17 \pm 0.18 \%$ dan perlakuan tanpa penambahan probiotik (B) adalah $2,63 \pm 0.06 \%$. Protein efisiensi rasio merupakan nilai yang menunjukkan jumlah bobot ikan yang dihasilkan dari tiap unit berat protein dalam pakan dengan asumsi bahwa semua protein digunakan untuk pertumbuhan. Hasil penelitian menunjukkan penambahan probiotik pada pakan lele berpengaruh terhadap rasio efisiensi protein. Nilai kecernaan protein pada perlakuan pakan dengan ditambahkan probiotik menunjukkan lebih tinggi dibandingkan dengan perlakuan tanpa penambahan probiotik. Hal ini diduga bakteri tersebut mampu menghasilkan enzim-enzim yang dapat membantu ikan 
untuk mencerna protein dalam protein. Protein Efficiency Ratio (PER) merupakan perbandingan antara pertambahan bobot ikan dan bobot protein pakan yang dikonsumsi (Afrianto dan Liviawaty, 2005). PER berfungsi untuk mengetahui jumlah protein yang terserap dalam tubuh ikan. Perlakuan dengan penambahan bakteri probiotik lebih baik dibandingkan dengan perlakuan tanpa penambahan bakteri probiotik karena lele dumbo mampu memanfaatkan keberadaan mikrobial flok sebagai pakan tambahan. Penelitian Crab et al. (2009) mencatat kandungan protein yang terdapat pada bioflok mencapai $42 \%$ dalam berat kering.

Menurut Arief et al., (2008), pemanfaatan Bacillus sp. memberikan pengaruh positif bagi pertumbuhan, enzim yang dihasilkan oleh bakteri yang ikut termakan akan membantu proses pencernaan dalam saluran pencernaan kultivan, selanjutnya dilaporkan bahwa bakteri ini akan menghasilkan enzim protease dan lipase. Menurut Rahmawan et al., (2014), menyatakan nilai PER dipengaruhi oleh kadar protein dan komponen lain dalam bahan makanan. Keseimbangan protein penting dalam formulasi pakan karena berperan besar dalam pertumbuhan, serta ketahanan tubuh ikan.
Pakan yang baik harus mengandung nutrisi yang lengkap. Kandungan nutrisi tersebut berfungsi untuk kelangsungan hidup. Pemberian bakteri probiotik melalui pakan dilakukan bertujuan agar dapat mendegradasi protein, lemak maupun karbohidrat dalam tubuh lele. Menurut Setiawati (2013) pemberian bakteri dalam pakan juga diharapkan dapat masuk dalam saluran pencernaan ikan sehingga dapat memperbaiki kemampuan ikan dalam mencerna pakan. Menurut Ibbaren et al., (2012) penggunaan bakteri probiotik merupakan salah satu solusi internal untuk menghasilkan pertumbuhan dan efisiensi pakan yang optimal, mengurangi biaya produksi sehingga pada akhirnya dapat mengurangi beban lingkungan karena akumulasi limbah di media pemeliharaan.

Berdasarkan hasil pengamatan laju pertumbuhan relatif (RGR) pada perlakuan pakan dengan penambahan probiotik (A) adalah $14,77 \pm 0.66 \%$ dan perlakuan tanpa penambahan probiotik (B) adalah $11,73 \pm 0.74 \%$. Penambahan probiotik dalam pakan buatan diduga dapat meningkatkan nilai RGR pada ikan lele dumbo.Pakan pada perlakuan B memberikan performa ikan lele dumbo yang lebih rendah dibandingkan dengan perlakuan A. Hal ini diduga karena pakan B tidak ditambahkan probiotik. Sehingga 
kandungan protein dalam pakan lebih rendah setelah dilakukan uji proksimat. Penelitian yang dilakukan Hanief et al., (2014) menunjukkan bahwa perbedaan komposisi campuran dalam formulasi pakan mempengaruhi nilai rasio efisiensi protein, dimana seiring dengan meningkatnya kadar protein pada formulasi pakan akan meningkatkan nilai rasio efisiensi protein pada ikan.

Penambahan probiotik pada pakan juga turut membantu proses pencernaan dengan baik sehingga mampu digunakan ikan untuk tumbuh dengan baik. Hal ini sesuai dengan pernyataan Sabariah (2010) yang menyatakan bahwa penambahan isolat probiotik pada pakan dapat meningkatkan laju pertumbuhan ikan. Pertumbuhan merupakan proses yang terjadi di dalam tubuh organisme yang menyebabkan pertambahan bobot atau protein dalam jangka waktu tertentu. Secara morfologis pertumbuhan diwujudkan dalam perubahan bentuk (metamorfosis), sedangkan secara energenetik pertumbuhan dapat diekspresikan dengan perubahan kandungan total energi (kalori) tubuh pada periode tertentu (Anggoro, 2007). Pemberian probiotik dalam pakan pada memberikan pengaruh yang nyata terhadap laju pertumbuhan spesifik lele dumbo. Bakteri kandidat probiotik yaitu Bacillus subtilis, Bacillus lincheniformis,
Pseudomonas putida yang dicampurkan pada pakan diduga mampu memberikan pengaruh yang sangat nyata terhadap pertumbuhan lele dumbo.

Kecernaan pakan meningkat dengan adanya penambahan probiotik dalam pakan dibandingkan dengan pakan tanpa pemberian probiotik. Enzim-enzim ini khusus yang dimiliki oleh bakteri ini sangat membantu dalam pemecahan molekul kompleks menjadi molekul sederhana sehingga akan mempermudah pencernaan lanjutan penyerapan oleh saluran pencernaan ikan. Peningkatan nilai nutrisi pakan dengan probiotik memiliki mekanisme dalam menghasilkan beberapa enzim exogenuos untuk pencernaan pakan seperti amilase, protase, lipase, dan selulase. Enzim exogenous tersebut akan membantu enzim endogenous di inang untuk menhidrolisis nutrien pakan (Anggoro, 2007).

Laju pertumbuhan berhubungan dengan pertambahan bobot tubuh ikan yang dihasilkan dari pemanfaatan nutrisi dalam pakan. Tingkat pertumbuhan ikan lele dumbo mengalami peningkatan dikarenakan kebutuhan protein, lemak dan karbohidrat sudah mencukupi dan sesuai dengan kebutuhan ikan untuk melakukan pertumbuhan. Menurut Anggraeni dan Rahmiati (2016) menyatakan tinggi rendahnya kandungan protein optimum dalam pakan dipengaruhi oleh lemak dan 
karbohidrat yang cukup. Tanpa karbohidrat dan lemak yang cukup ikan menggantungkan energinya sebagian besar dari protein pakan, yang akan digunakan sebagai sumber energi untuk mencerna makanan dan proses metabolisme. Menurut Ariati (2013), keseimbangan yang tepat antara energi dan protein pakan sebagian besar dipenuhi oleh nutrien nonprotein seperti lemak dan karbohidrat. Apabila energi yang berasal dari sumber non-protein cukup maka sebagian besar protein akan dimanfaatkan untuk tumbuh, namun apabila energi dari non-protein tidak terpenuhi maka protein akan digunakan sebagai sumber energi sehingga fungsi protein sebagai pembangun tubuh akan berkurang

Berdasarkan Uji-t menunjukkan bahwa penambahan probiotik pada pakan buatan memiliki pengaruh nyata $(\mathrm{P}<0,05)$ terhadap kelulushidupan ikan lele $(C$. gariepinus) hal ini diduga bahwa pakan dengan penambahan probiotik pada pakan buatan memberikan pengaruh pada pertumbuhan, dan memberikan pengaruh nyata terhadap tingkat kelulushidupan. Nilai rata-rata kelulushidupan (SR) antar perlakuan berbeda nyata, rata-rata SR perlakuan pakan dengan penambahan probiotik (A) adalah $97,92 \pm 0,29 \%$ dan perlakuan tanpa penambahan probiotik (B) adalah 96,79 $\pm 0,16 \%$. Menurut Fitria (2012), tingkat kelangsungan hidup sangat dipengaruhi oleh kualitas air terutama suhu dan kandungan oksigen. Suhu merupakan salah satu faktor yang mempengaruhi pertumbuhan. Suhu dapat mempengaruhi aktifitas ikan, seperti pernafasan dan reproduksi. Suhu air sangat berkaitan dengan konsentrasi oksigen terlarut dan laju konsumsi oksigen ikan faktor

Tingkat kelulushidupan yang baik dipengaruhi oleh kondisi lingkungan yang optimal. Kondisi lingkungan yang baik dapat memungkinkan ikan tumbuh dengan baik. Menurut Trisnawati et al., (2014) yang dapat mempengaruhi tinggi rendahnya kelulushidupan suatu organisme adalah faktor biotik dan abiotik. Faktor biotik antara lain kompetitor, kepadatan populasi, umur dan kemampuan organisme dengan lingkungan sedangkan faktor abiotik seperti suhu, oksigen terlarut, $\mathrm{pH}$ dan kandungan ammonia.

\section{Evaluasi Variabel Kualitas Air}

Hasil pengamatan kualitas air pemeliharaan termasuk layak untuk kehidupan lele dumbo. Suhu tersebut cukup sesuai dengan kondisi ikan lele. Menurut SNI (2015) kisaran suhu untuk ikan lele (Clarias sp) antara $22-32{ }^{\circ} \mathrm{C}$. Sesuai pendapat Madinawati et al., (2011) 
bahwa suhu air berpengaruh terhadap pertumbuhan dan perkembangan ikan. Ikan lele dumbo dalam penelitian ini hidup pada suhu air berkisar antara $25-30^{\circ} \mathrm{C}$. Suhu air yang sesuai akan meningkatkan aktivitas makan ikan, sehingga menjadikan ikan lele dumbo cepat tumbuh.

Oksigen terlarut yang diukur selama penelitian menunjukan hasil 34-6 mg/L. Hasil pengamatan dari variabel oksigen terlarut tersebut masih sesuai untuk budidaya ikan lele. Menurut SNI (2015) kebutuhan oksigen minimal $3 \mathrm{mg} / \mathrm{L}$. Menurut Rachmawati et al., (2015) konsentrasi oksigen yang baik untuk ikan lele tidak boleh kurang dari $3 \mathrm{mg} / \mathrm{l}$. Oksigen yang rendah umumnya diikuti dengan meningkatnya amoniak dan karbondioksida di air yang menyebabkan proses nitrifikasi menjadi terhambat sehingga mengganggu kelulushidupan ikan.

Nilai $\mathrm{pH}$ yang diperoleh pada saat penelitian yaitu 7-7,5 hasil dari variabel tersebut masih dalam batas kelayakan. Menurut Ahmadi et al., (2012) pH produktif perairain bagi pertumbuhan benih lele sangkuriang antara 6,5-8,6.

Nilai ammonia yang diperoleh selama penelitian yaitu $0-0,035 \mathrm{mg} / \mathrm{L}$, kandungan tersebut masih dalam batas kewajaran. Menurut Hastuti dan Subandiyono (2014), kandungan ammonia dalam budidaya ikan lele system bioflok selama penelitian adalah berkisar 0,26 3,23 $\mathrm{mg} / \mathrm{L}$. Konsentrasi ammonia yang baik untuk pertumbuhan dan perkembangan ikan lele yaitu maksimal 0,1 mg/L. Menurut Effendi (2003) kadar nitrit pada perairan mampu untuk menunjang kehidupan yaitu dibawah 1 $\mathrm{mg} / \mathrm{L}$.

Penggunaan probiotik tersebut ternyata mampu menyeimbangkan variabelvariabel kualitas air pada kadarnya. Bakteri ini diduga juga mampu memperbaiki kualitas air selama percobaan. Menurut Irianto (2003) menyatakan bahwa penggunaan Bacillus sp. mampu memperbaiki kualitas air melalui penyeimbangan populasi mikroba dan mengurangi jumlah patogen dan secara bersamaan mengurangi penggunaan senyawa-senyawa kimia serta meningkatkan pertumbuhan hewan air. Bakteri B. subtilis dan B. megaterium ternyata berhasil menurunkan kadar nitrogen hingga 5,4 mg/L dan COD 40,8 $\mathrm{mg} / \mathrm{L}$, serta transparansi air hingga 30-50 cm (Irianto, 2003).

\section{KESIMPULAN DAN SARAN}

\section{Kesimpulan}

Kesimpulan yang dapat diambil dari hasil penelitian adalah sebagai berikut:

1. Penambahan probiotik dalam pakan buatan dari limbah pertanian berpengaruh nyata terhadap efisiensi 
pemanfaatan pakan (EPP), rasio konversi pakan (FCR), rasio efisiensi protein (PER), laju pertumbuhan relatif (RGR), dan kelulushidupan (SR), namun tidak memberikan pengaruh yang nyata terhadap tingkat konsumsi pakan (TKP) ikan lele dumbo (Clarias gariepinus) strain Sangkuriang

2. Penambahan probiotik dari campuran bakteri Lactobacillus casei, Saccharomyces cerevisiae, Bacillus subtilis, Bacillus lycheniformis, dan Lactobacillus plantarum (hasil kultur dari Laboratorium Akuakultur, Fakultas Perikanan dan Ilmu Kelautan), pada pakan buatan mandiri dengan sumber bahan baku utama dari limbah pertanian, sebanyak 2,5 ml ditambah $5 \mathrm{ml}$ molase dan $250 \mathrm{ml}$ air biasa atau air kolam/1 $\mathrm{Kg}$ pakan $\left(10^{7}\right.$ CFU/g pakan), kemudian dicampur secara homogen ke permukaan pakan menghasilkan efisiensi pemanfaatan pakan (EPP): 99,56 $\pm 5,64 \%$, rasio konversi pakan (FCR): 0,88 $\pm 0,04$, rasio efisiensi protein (PER): $3,17 \pm 0.18$, laju pertumbuhan relative (RGR):14,77 $\pm 0.66 \% /$ hari, dan tingkat kelulushidupan (SR): 98,92 $\pm 0,29 \%$.

\section{Saran}

Saran yang dapat diberikan pada penelitian ini adalah sebagai berikut:

1. Didalam pengembangan pakan mandiri (Gerpari/Gerakan pakan mandiri), dapat menggunakan bahan baku dari limbah produk pertanian seperti tepung ari jagung, ari gandum, bungkil kedelai, bekatul dan telur ayam afkir serta tepung ikan rucah hasil limbah penangkapan ikan di laut untuk dibuat pakan berupa pellet yang cukup nilai nutrisi dan penggunaan probiotik pada pakan bagi pertumbuhan dan tingkat kelulusanhidupan ikan lele yang dipelihara.

2. Sebaiknya penambahan probiotik dalam pakan buatan dari limbah pertanian adalah $10^{7} \mathrm{CFU} / \mathrm{g}$ pakan atau melalui prosedur dengan dosis 2,5 $\mathrm{ml}$ probiotik ditambah $5 \mathrm{ml}$ molase energy dan ditambahkan 250 $\mathrm{ml}$ air sumur /air kolam untuk dicampurkan kepada pakan sebanyak $1 \mathrm{~kg}$ pakan, dan diinkubasi selama 48 jam agar dapat memanfaatkan pakan dan menghasilkan produksi yang optimal. 


\section{UCAPAN TERIMA KASIH}

Terimakasih kami sampaikan kepada Lembaga Penelitian dan Pengabdian Kepada Masyarakat (LPPM) Universitas Diponegoro yang telah membiayai penelitian ini melalui Program Penguatan Komoditi Unggulan Masyarakat (PKUM) sumber dana selain APBN Undip Tahun Anggaran 2018 sesuai dengan surat penugasan pelaksanaan, nomor: 47504/UN7.P4.3/PM/2018.

\section{DAFTAR PUSTAKA}

Muchlisin, Z. A., , M. Junaidi, Paryono, N. Cokrowati dan S. Yuniarti. 2015. Pertumbuhan dan Konsumsi Pakan Ikan Lele (Clarias sp.) yang Diberi Pakan Berbahan Baku Lokal. J. Depik. 4(1): 3339.

Ahmadi, H., Iskandar., N. Kurniawati. 2012. Pemberian Probiotik dalam Pakan Terhadap Pertumbuhan Lele Sangkuriang (Clarias gariepinus) pada Pendederan II. J. Perikanan dan Kelautan. 3(4): 99107.

Afrianto, E dan E. Liviawaty. 2005. Pakan Ikan. Kanisius. 146 hlm.

Amalia, R., Subandiyono dan E. Arini. 2013. Pengaruh Penggunaan Papain terhadap Tingkat Pemanfaatan Protein Pakan dan Pertumbuhan Lele Dumbo (Clarias gariepinus). Jurnal of Aquaculture Management and Technology. 2 (1): 136-143.

Amin, M. 2007. Pengaruh Enzim Fitase dalam Pakan Terhadap Kecernaan Nutrien dan Kinerja Pertumbuhan Ikan Lele Dumbo (Clarias sp.).
[Thesis]. Sekolah Pascasarjana, Institut Pertanian Bogor, Bogor, $56 \mathrm{hlm}$.

Anggraeni, D. N dan Rahmiati. 2016. Pemanfaatan Ampas Tahu Sebagai Pakan Ikan Lele (Clarias batrachus) Organik. Biogenesis. 4(1): 53-57.

Ardita, N., A. Budiharjo dan S. L. A. Sari. 2015. Pertumbuhan dan Rasio Konversi Pakan Ikan Nila (Oreochromnis niloticus) dengan Penambahan Prebiotik. Bioteknologi. 12(1): 16-21.

Ariati, R. 2013. Pengaruh Pemberian Tepung Kepala Udang Terhadap Laju Pertumbuhan dan Konversi Pakan Benih Lele Sangkuriang (Clarias Gariepinus). [Skripsi].Universitas Padjajaran. $25 \mathrm{hlm}$.

Arief, M., Mufidah dan Kusriningrum. 2008. Pengaruh Penambahan Probiotik Pada Pakan Buatan Terhadap Pertumbuhan dan Rasio Konversi Pakan Ikan Nila Gift (Oreochromisniloticus). Berkala Ilmiah Perikanan, 3(2): 53-58.

Arief, M., N. Fitriani dan S. Subekti. 2014. Pengaruh Pemberian Probiotik berbeda pada Pakan Komersil Terhadap Pertumbuhan dan Efisiensi Pakan Ikan Lele Sangkuriang (Clarias sp.). J. Ilmiah Perikanan dan Kelautan. 6(1): 49-53

Crab, R., B. Chielens, M. Wille, P. Bossier and W. Verstraete. 2009. The Effect of Different Carbon Sources on The Nutritional Value of Bioflocs, a Feed for Macrobrachium rosenbergii Postlarvae. Aquaculture Research, 41: 559-567. 
De Silva, S.S. 1987. Finfish Nutritional Research in Asia. Proceeding of The Second Asian Fish Nutrition Network Meeting. Heinemann, Singapore. $128 \mathrm{p}$.

Effendie, M.I. 1997. Biologi Perikanan. Yayasan Pustaka Nusantara, Yogyakarta, $163 \mathrm{Hlm}$.

Effendi, H. 2003. Telaah Kualitas Air. Kanisius. Yogyakarta. 78 hlm.

Fitria, A.S. 2012. Analisis Kelulushidupan dan Pertumbuhan Benih Ikan Nila Larasati (Oreochromis niloticus) F5 D30-D70pada Berbagai Salinitas. Fakultas Perikanan dan Ilmu Kelautan, Universitas Diponegoro. J. of Aquaculture Management and Technology. 1(1): 18-34.

Fujaya, Y. 2004. Fisiologi Ikan (Dasar Pengembangan Teknik Perikanan). Rineka Cipta, Jakarta. $149 \mathrm{Hlm}$.

Fran, S. dan J. Akbar. 2013. Pengaruh Perbedaan Tingkat Protein dan Rasio Protein Pakan terhadap Pertumbuhan Ikan Sepat (Trichogaster pectoralis). Fish Scientiae. 3(5): 53-63.

Hanief, M. A. R., Subandiyono dan Pinandoyo. 2014. Pengaruh Frekuensi Pemberian Pakan terhadap Pertumbuhan dan Kelulushidupan Benih Tawes (Puntius javanicus). J. of Aquaculture Management and Technology. 3(4): 67-74.

Hastuti, S dan Subandiyono. 2014. Performa Produksi Ikan Lele Dumbo (Clarias gariepinus) yang Dipelihara dengan Teknologi Biofloc. J. Of Fisheries Science and Technology (IJFST). 10(1): $37-42$.

Anggoro, S. 2007. Teknik Domestikasi Udang Liar Metapenaeus elegans ( Udang Jahe) Asal Segara Anakan melalui optimalisasi Media dan Pakan. 96 hlm.

Irianto, A., P. A. W. Robertson and B. Austin, 2003. Oral administration of formalin-inactivated cells of Aeromonas hydrophila A3-51 controls infection by atypical A. salmonicida in goldfish, Carassius auratus (L.). Journal of Fish Diseases, 26: 117-120.

Iribbaren, D., P. Daga. and M. T. Moreira., G. Feijoo. 2012. Potential Environmental Effects of Probiotics Used in Aquaculture. Aquacult Int 20:779-789

Kennedy, S.B., Jr. Tucker., J. W. Neidic., L. Carole., G. K. Cooper., J. L. Jarrell. and D.G. Sennett. 1998. Bacterial management strategies for stock enhancement of warmwater marine fish: A case study with common snook (Centropomus undecimalis). Bulletin of Marine Science, 62: 573-588.

Pereira, L., T. Riquelme and $\mathrm{H}$. Hosokawa. 2007. Effect of There Photoperiod Regimes on the Growth and Mortality of the Japanese Abalone (Haliotis discus hanaino). [Skripsi]. Kochi University, Aquaculture Department, Laboratory of Fish Nutrition, Japan, 26: 763-767 p.

Rachmawati, D., I. Samidjan dan H. Setyono. 2015. Manajemen Kualitas Air Media Budidaya Ikan Lele Sangkuriang (Clarias 
gariepinus) dengan Tekni Probiotik pada Kolam Terpal Di Desa Vokasi Reksosari, Kecamatan Suruh, Kabupaten Semarang. Pena Akuatik Indonesia. 12(1): 24-32.

Rahmawan, H., Subandiyono dan E. Arini. 2014. Pengaruh Penambahan Ekstrak Pepaya dan Ekstrak NanasTerhadap Tingkat Pemanfaatan Protein Pakan dan PertumbuhanLobster Air Tawar (Cherax Quadricarinatus). J. Of Aquaculture Management and Technology. 3 (4): 75-83.

Sabariah. 2010. Seleksi Bakteri Probiotik dari Saluran Pencernaan untuk Meningkatkan Kinerja Pertumbuhan Ikan Jelawat (Leptobarbus Hoeveni Blkr). Tesis. IPB: Bogor. 54 hlm.

Setiawati, J.A., Y.T Tarsim, Adiputra dan S. Hudaidah. 2013. Pengaruh Penambahan Probiotik pada Pakan dengan Dosis Berbeda terhadap Pertumbuhan, Kelulushidupan, Efisiensi Pakan dan Retensi Protein Ikan Patin (Pangasius hypophthalamus). EJurnal Rekayasa dan Teknologi Budidaya Perairan I (2) : 151162.

Srigandono, B. 1992. Rancangan Percobaan. Fakultas Peternakan, Universitas Diponegoro, Semarang, $178 \mathrm{hlm}$.

Standar Nasional Indonesia. 01-4087. 2015. Pakan Buatan Untuk Ikan Lele Dumbo (Clarias gariepinus) pada Budidaya Intensif.

Sudjana. 1991. Desain dan Analisis Eksperimen Edisi III. Tarsito, Bandung, 56.

Tacon, A. E. J. 1993. Feed Ingredient for Warmwater Fish: Fish Meal and
Other Processed Feedstuffs. AO Fisheries Circular, 856: 64 pp

Takeuchi, T. 1988. Laboratory workchemical evaluation of dietary nutriens. In: Watanabe, T. (Edo, Fish Nutrition and Mariculture, JICA, Tokyo Univ, Fish, pp. 179 -229 .

Trisnawati, Y., Suminto dan A. Sudaryono. 2014. Pengaruh Kombinasi Pakan Buatan dan Cacing Tanah (Lumbricus rubellus) terhadap Efisiensi Pemanfaatan Pakan, Pertumbuhan dan Kelulushidupan Lele Dumbo (Clarias gariepinus). J. Of Aquaculture Management And Technology. 3(2): $86-93$.

Watson, A. K., H. Kaspar, M. J. Lateganand L. Gibson. 2008. Probiotics inAquaculture: The Need, Principles and Mechanisms of Action and ScreeningProcesses. Aquaculture, 274: $1-14$.

Widanarni, D.,Wahjuningrum, dan M. Setiawati. 2009. Optimasi Budidaya Super-Intensif Ikan Nila Ramah Lingkungan: Dinamika Mikroba Bioflok. Fakultas Perikanan dan Ilmu Kelautan, Institut Pertanian Bogor. 40 hlm.

Yoel, B. Sundu dan F. Y. Tantu. 2016. Pertumbuhan dan Kecernaan Protein Ikan Lele Sumbo (Clarias gariepinus) yang Diberi Pakan Berbasis Tepung Usus Ayam Sebagai Pengganti Tepung Ikan. e-Jurnal Mitra Sains. 4(1): 20-28. 